\title{
The effect of extract of bitter leaf (Vernonia amygdalina) on blood glucose levels of diabetic rats
}

\author{
Reginald Nwazue NWAOGUIKPE \\ Medical Biochemistry Unit, Department of Biochemistry, Federal University of Technology, P.M.B. 1526, \\ Owerri, Imo State, Nigeria.E-mail: coconacik@yahoo.com
}

\begin{abstract}
Twenty-four (24) adult albino Wistar rats (twelve males and twelve females) were used for the study. The animals were divided into six groups of four rats in each. Proximate analysis was carried out on the plant sample with the following results: crude protein $22.45 \pm 0.01 \%$; crude fat $(3.45 \pm 0.0 \%)$; crude fiber $(16.0 \pm$ $0.0 \%)$ and Ash $(9.95 \pm 0.2 \%)$. Quantitative phytochemical analysis revealed the presence of flavonoids $(0.85 \pm$ $0.11 \mathrm{mg})$, tannins $(0.37 \pm 0.2 \mathrm{mg})$, saponins $(2.2 \pm 0.0 \mathrm{mg})$, polyphenol $(0.35 \pm 0.11 \mathrm{mg})$, alkaloids $(2.13 \pm 0.10$ $\mathrm{mg})$ and $\mathrm{HCN}(12.25 \pm 0.10 \mathrm{mg})$. Some of the vitamins analyzed included: Vitamin A $345.50 \pm 0.0 \mathrm{IU})$, Vitamin C $(228.40 \pm 0.0 \mathrm{mg})$, Vitamin E $(37.30 \pm 0.01 \mathrm{mg})$, Vit.B $_{1}(1.0 \pm 0.00 \mathrm{mg}), \mathrm{Vit}_{2} \mathrm{~B}_{2}(3.10 \pm 0.00 \mathrm{mg}), \mathrm{Fe}$ $(11.0 \pm 0.0 \mathrm{mg})$ and Niacin $(0.41 \pm 0.0 \mathrm{mg})$ respectively. Hyperglycemia was induced in the rats using alloxan. The plant extract of Vernonia amygdalina (bitter leaf) was administered to the rats orally at concentrations of $2 \%, 4 \%, 6 \%, 8 \%$ and $10 \%$ before meals for 5,10 and 15 days respectively after which, blood samples were collected from the animals and analyzed for glucose levels using enzymatic methods. There was a remarkable decrease in blood glucose level from the mean value of $4.44 \pm 0.2$ to $1.66 \pm 0.2 \mathrm{mmol} / \mathrm{L}$. The decrease in the blood glucose level of the rats following the administration of the plant extract suggests that the plant extract possesses anti-diabetic, anti-hyperglycemic and hypoglycemic effects on alloxan induced diabetic rats. The presence of phytochemicals, vitamins and other nutrients such as proteins, lipids, carbohydrates, ash and other components in the extract must have acted synergistically to potentiate the anti-diabetic role of the plant extract.
\end{abstract}

(c) 2010 International Formulae Group. All rights reserved.

Keywords: Diabetes mellitus, hyperglycemia, diabetic rats, Vernonia amygdalina.

\section{INTRODUCTION}

The usefulness of plants to man is not only as a source of raw materials for industries, but also as a source of food and medication. From earliest times, plants have provided man with diverse means of healing. Many parts of plants such as fruits, seeds, barks, roots, fruits and flowers have been used as medicaments to cure various diseases that afflict man and other animals (Phyllistin et al., 2000). In some of the western countries like
China and India, the primary healthcare system enjoys supportive armament from the use of plants and plant products especially for the treatment of many diseases (Sofowara, 2006). In Nigeria, most communities especially in the South-South, South-East and South-West geo-political zones broadly use herbal medicines to treat various diseases and ailments which include: asthma, tuberculosis, ulcers, diarrhea, dysentery, to mention but a few. Plants have been known to contain or 
possess abundant phytochemicals, antimicrobials and pharmacologically active principles, which include: anthraquinones, flavonoids, saponins, polyphenols, tannins and alkaloids (Sofowara, 2006; Evans, 2005; Erasto et al., 2006). Several herbal preparations from different parts of plants (leaves, roots, barks and twigs) have become popular for the treatment of a variety of diseases such as diabetes mellitus, breast cancer, hypertension, etc. (Pinto and Rivlin, 1999; Li and Schellhorn, 2007). One of such plants suspected to possess medicinal value is the bitter leaf (Vernonia amygdalina). Bitter leaf is a common plant in the South-Eastern part of Nigeria. Vernonia amygdalina grows throughout tropical Africa and has been domesticated in some parts of Nigeria. It is a small tree of about 1-3 m tall, occurs as a herb or shrub in Madagascar and Asia (Ojiako and Nwanjo, 2006; Izevbigie et al., 2004) and belongs to the plant family, the compositae. It has a chromosome number $2 \mathrm{n}=40$. In Nigeria, the Edo people call it "Oriwo", Hausa "Chuserdek" (a horse tonic food, containing the leaves), Yoruba "Ewuro", and the Ibos "Onugbo".

Studies on the nutritional composition of the bitter leaf (Vernonia amygdalina) are numerous (Nimenibo-Uadia, 2003). Vernonia amygdalina has been found to be rich in minerals, especially phosphorus, calcium, potassium, magnesium, zinc,iron and some vitamins like vitamin $\mathrm{A}, \mathrm{C}$ and $\mathrm{E}$. Scientific and pharmacological studies have revealed the antihyperglycemic action of the roots (Nimenibo-Uadia, 2003). Extracts from the leaves have been reported to posses hypolipidemic and antihyperlipidemic properties and have been found to protect the kidneys and livers of alloxan diabetic rats against complications (Atangwho et al., 2007a, 2007b, 2007c). In folkloric medicine, it was used to cure a lot of diseases including eczema, measles and anemia (Akinpelu, 1999; Ohigeshi et al., 1991; Akindahunsi and Salawu, 2005). Glucose is a monosaccharide and the form in which carbohydrate is absorbed through the intestinal tract and circulated in the body. Glucose is stored as glycogen in the liver and starch in plants and seeds (Nelson and Cox, 2005). Glucose is an important source of energy in the body of animals. It has been discovered that brain cells require over 120 grams of glucose for its functions daily (Cheesbrough, 1999; Garrett and Grisham, 2005). Diabetes mellitus has become a common disease, very prevalent in many countries of the world affecting all ages in developing and developed nations (Amos and McCarty, 1997). The prevalence of diabetes mellitus in some countries has reached $1-2 \%$ of the total population and in Africa, it is on increase. There are basically two main classes of diabetes mellitus: Type 1 (Insulin-dependent diabetes mellitus, IDDM). This starts early in life, common during childhood and always severe or fulminating. It results from deficiency of insulin due to pancreatic cell damage resulting in low plasma level of the hormone (Mbaya et al., 1996). Insulin dependent diabetes mellitus require insulin therapy to control the hyperglycemia. Type II (Non-insulin dependent diabetes mellitus, NIDDM). This is the most common form of diabetes mellitus and referred to as "Adult onset diabetes mellitus" more prevalent in adult life. The plasma insulin level may be higher than in type 1, and sometimes may even be normal, but there may be insulin resistance; patients are less likely to develop ketosis (Vasudevan and Screekumari, 2007). Sufferers may either be obese NIDDM or non-obese NIDDM (Kendall, 2007). The treatment of diabetes mellitus so far is to administer more insulin to enable the diabetic attains nearly normal carbohydrate, fat and protein metabolism (Nelson and Cox, 2005). The use of antidiabetic drugs like sulfonylureas, biguanides and intravenous insulin injection has advantages. The most important side effect of the sulfonylureas is hypoglycemia and if not checked, can lead to death (Erasmus et al., 1999). Diabetes can also be managed by exercise, diet and pharmaceutical drugs, which are very expensive and possess unfavorable side effects. The WHO 
recommended the use of alternative therapy, especially in countries where access to conventional management procedures is inadequate. To this effect, the search for more effective hypoglycemic and antihyperglycemic agents becomes very paramount. The objective of the research work is to demonstrate experimentally, the antidiabetic, antihyperglycemic and hypoglycemic effects of bitter leaf (Vernonia amygdalina) extract on alloxan induced diabetic albino rats.

\section{MATERIALS AND METHODS \\ Materials}

The materials used in this research included: Nickel-Electro bench centrifuge, (Unicam Spectronic-20DR) spectrophotometer, oxalate bottles, alcohol, glucose test kit, xylene, alloxan, all purchased from Ames Biochemical, London. Albino rats (Wistar) were purchased from the department of Biochemistry Animal House, University of Portharcourt, Nigeria, and bitter leaves were bought from a local market in Owerri, Imo State, Nigeria, and authenticated by a horticulturist at the Department of Crop Science and Technology of the Federal University of Technology, Owerri, as being of high nutritional quality.

\section{Methods}

Twenty four (24) Wistar albino rats (12 males and 12 females species) weighing between 140-170 g body weight, were obtained from the animal house of the department of Biochemistry, University of PortHarcourt, Nigeria. The rats were divided into six groups (6) of four animals in each cage and were allowed access to water and standard pellet food. Prior to the administration of extract, the rats were denied access to water for 12 hours but had access to food.

\section{Preparation of plant extract}

The leaves of Vernonia amygdalina were washed completely with distilled water and sodium chloride solution to remove contaminants. The leaves were air dried at room temperature of $27{ }^{0} \mathrm{C}$ to a constant weight and ground into a powder, sieved to regrind the coarse samples. Ten $(10 \mathrm{~g})$ grams of the powdered sample were soaked in 150 $\mathrm{ml}$ of distilled water and the mixture allowed standing for 24 hours with occasional shaking. The resulting mixture was filtered using cheese cloth and the filtrate stored in a glass bottle. The extract of $10 \%$, served as stock solution. From this stock solution, $4 \%$ stock solution was prepared by dilution. Subsequent dilutions were made to get; $2 \%, 4 \%, 6 \%$ and $8 \%$ respectively. All solutions were stored in a refrigerator until used.

\section{Chemical analysis of leaves}

The ash, crude fat, crude protein, carbohydrate and crude fiber contents were determined using the standard methods of the Association of Official Analytical Chemists (AOAC, 2000). Vitamins A, B $\mathrm{B}_{2}, \mathrm{~B}_{1}, \mathrm{C}, \mathrm{E}, \mathrm{Fe}$ and Niacin were determined spectrophotometrically using the standard methods of AOAC (2000). Quantitative phytochemical compositions of the leaves were determined using the methods previously described by Harbone (1998), Evans (2005) and Sofowara (2006).

\section{Statistical analysis}

All data were expressed as Mean \pm S.D from triplicate determinations and the differences between the groups considered using ANOVA and the Waller-Duncan test at $\mathrm{p} \leq 0.05$.

\section{Administration of alloxan ${ }^{\text {tm }}$ \\ Wistar albino rats of about two months and three weeks old with average weight of $160 \mathrm{~g}$ were made diabetic by injecting $1 \mathrm{ml}$ of Alloxan intraperitoneally. Development of diabetes was allowed for 4 days (96 hours) after which the blood glucose level was analyzed and determined by the method of glucose-enzyme kit analysis.}

\section{Collection of blood samples}

Blood samples were collected from the tail of the rats after 4 days of administration of 
Alloxan. The animals were held by their heads and their tails were rubbed with xylene. This could equally be done using warm water, by dipping their tails in it. Both reagents (xylene and water) cause dilation of the vessels, ensuring the collection of large volume of blood by skinning a length of $1 \mathrm{~cm}$ from the tail with very sharp scissors. The wounded tails were rubbed with absolute ethanol to prevent infection. About $1 \mathrm{ml}$ of blood was collected into fluoride/oxalate bottles and only $0.1 \mathrm{ml}$ was used for blood glucose analysis.

\section{Administration of the extracts}

The rats were divided into six (6) groups of 4 rats in each group including the control. The last group was the control. The animals were given the extracts once every morning orally before meals. After periods of 5 days, 10 days and 15 days of administration of the extract, blood samples were collected by cardiac puncture using a sterile needle to pierce the heart after dissecting the anaesthetized rats. The scheme below shows the arrangement of the rats in groups.

Group 1 - diabetic rats received $1 \mathrm{ml}$ of $2 \%$ extract

Group 2 - diabetic rats received $1 \mathrm{ml}$ of $4 \%$ extract

Group 3 - diabetic rats received $1 \mathrm{ml}$ of $6 \%$ extract

Group 4 - diabetic rats received $1 \mathrm{ml}$ of $8 \%$ extract

Group 5 - diabetic rats received $1 \mathrm{ml}$ of $10 \%$ extract

Group 6 - non-diabetic rats received $1 \mathrm{ml}$ of $2 \%$ extract

The plant extract was administered by compulsory oral intubations.

\section{Glucose estimation}

Blood glucose was measured by using the glucose oxidase method (Cheesbrough, 1999). The results of the blood glucose level estimation were determined before and after the administration of alloxan and extracts. Hyperglycemia, induced in rats was assessed after 96 hours (4 days), the blood sugar values expressed in $\mathrm{mmol} / \mathrm{L}$ and these were given as Mean \pm S.D.

\section{RESULTS}

The results obtained in the analyses are shown in Tables 1-5. Table 1 shows the proximate composition of the leaves. Table 2 shows the vitamin composition of the leaves. Table 3 shows the quantitative phytochemical composition of the leaves. Table 4 shows the blood glucose levels of the rats before and after induction of diabetes mellitus by alloxan. Table 5 shows the blood glucose levels before and after administration of the plant extract to the animals including the control group. homayodo.

The Tables show a general increase in the blood glucose level in the rats following the administration of alloxan except in group six (6) animals where diabetes mellitus was induced. There was a mean increase from 3.38 \pm 0.64 to $4.44 \pm 0.12 \mathrm{mmol} / \mathrm{L}$

The result in Table 5 showed a decrease in the blood glucose levels in the diabetic rats treated with the bitter leaf extract. The difference in the concentration of the extracts, $2 \%, 4 \%, 6 \%, 8 \%$ and $10 \%$ produced a significant hypoglycemic effect in the rats after 5, 10 and 15 days of administration of the extracts. The highest reduction was observed in group 4 rats that received $8 \%$ of the plant extract solution for 15 days. This dose of the extract elicited the highest reduction from a mean blood glucose value of $4.50 \pm 0.1-1.45 \pm 0.2 \mathrm{mmol} / \mathrm{L}$ for a diabetic condition. The non diabetic control (group 6) rats, receiving $2 \%$ extract solution equally showed a significant reduction in blood glucose level. This nonetheless shows the hypoglycemic effect of the extract on normal rats. All the results showed significant differences at $p \leq 0.05$. The values in the tables with the same superscript are significantly related at $p \leq 0.05$ along the rows and not along the columns for Tables 4 and 5 respectively. 
Table 1: Quantitative proximate composition of Vernonia amygdalina.

\begin{tabular}{l|c|c|c|c|c}
\hline Plant specie & $\begin{array}{c}\text { Crude } \\
\text { Carbohydrate } \\
(\boldsymbol{\%})\end{array}$ & $\begin{array}{c}\text { Crude } \\
\text { Protein } \\
(\boldsymbol{\%})\end{array}$ & $\begin{array}{c}\text { Crude } \\
\text { fat }(\boldsymbol{\%})\end{array}$ & $\begin{array}{c}\text { Crude fiber } \\
(\boldsymbol{\%})\end{array}$ & Ash (\%) \\
\hline $\begin{array}{l}\text { Vernonia } \\
\text { amygdalina }\end{array}$ & $22.45 \pm 0.01$ & $62.2 \pm 0.10$ & $3.45 \pm 0.00$ & $16.00 \pm 0.00$ & $9.95 \pm 0.2$ \\
\hline
\end{tabular}

Table 2: Some vitamins identified in the leaves of Vernonia amygdalina.

\begin{tabular}{l|c|c|c|c|c|c|c}
\hline Plant specie & $\begin{array}{c}\text { Vit.A } \\
(\mathbf{I U} / \mathbf{1 0 0 g})\end{array}$ & $\begin{array}{c}\text { Vit.E } \\
(\mathbf{I U} / \mathbf{1 0 0 g})\end{array}$ & $\begin{array}{c}\text { Vit.C } \\
(\mathbf{m g} / \mathbf{1 0 0 g})\end{array}$ & $\begin{array}{c}\text { Vit.. } \\
(\mathbf{m g} / \mathbf{1 0 0 g})\end{array}$ & $\begin{array}{c}\text { Vit. } \\
(\mathbf{\%})\end{array}$ & $\begin{array}{c}\mathbf{F e} \\
(\mathbf{m g} / \mathbf{1 0 0 g})\end{array}$ & Niacin \\
\hline $\begin{array}{l}\text { Vernonia } \\
\text { Amygdalina }\end{array}$ & $345.50 \pm 0.00$ & $37.30 \pm 0.01$ & $228.40 \pm 0.0$ & $3.10 \pm 0.0$ & $1.00 \pm 0.0$ & $11.0 \pm 0.0$ & $0.41 \pm 0.0$ \\
\hline
\end{tabular}

Table 3: Phytochemical composition of the leaves of Vernonia amygdalina.

\begin{tabular}{lcccccc}
\hline Plant specie & $\begin{array}{c}\text { Flavonoid } \\
(\boldsymbol{\%})\end{array}$ & $\begin{array}{c}\text { Tannins } \\
(\boldsymbol{\%})\end{array}$ & $\begin{array}{c}\text { Saponins } \\
(\boldsymbol{\%})\end{array}$ & $\begin{array}{c}\text { Polyphenols } \\
(\boldsymbol{\%})\end{array}$ & $\begin{array}{c}\text { Alkaloids } \\
(\boldsymbol{\%})\end{array}$ & $\begin{array}{c}\text { HCN } \\
(\mathbf{m g} / \mathbf{1 0 0 g})\end{array}$ \\
\hline $\begin{array}{l}\text { Vernonia } \\
\text { amygdalina }\end{array}$ & $0.85 \pm 0.11$ & $0.37 \pm 0.2$ & $2.2 \pm 0.10$ & $0.35 \pm 0.11$ & $2.13 \pm 0.10$ & $12.25 \pm 0.10$ \\
\hline
\end{tabular}

Table 4: Blood glucose levels before and after the administration of alloxan in the rats.

\begin{tabular}{lccc}
\hline Groups & $\begin{array}{c}\text { Glucose concentration } \\
(\mathbf{m m o l} / \mathbf{L}) \text { before induction } \\
\text { of diabetes }\end{array}$ & $\begin{array}{c}\text { Glucose conc. }(\mathbf{m m o l} / \mathbf{L}) \\
\text { after induction of } \\
\text { diabetes }\end{array}$ & $\begin{array}{c}\text { Difference } \\
(\mathbf{m m o l} / \mathbf{L})\end{array}$ \\
\hline 1 & $3.30 \pm 0.1^{\mathrm{a}}$ & $4.90 \pm 0.1^{\mathrm{a}}$ & $1.60 \pm 0.0^{\mathrm{b}}$ \\
2 & $3.50 \pm 0.2^{\mathrm{a}}$ & $4.70 \pm 0.1^{\mathrm{a}}$ & $1.20 \pm 0.1^{\mathrm{b}}$ \\
3 & $3.50 \pm 0.1^{\mathrm{a}}$ & $4.10 \pm 0.2^{\mathrm{b}}$ & $0.59 \pm 0.1^{\mathrm{c}}$ \\
4 & $3.30 \pm 0.0^{\mathrm{a}}$ & $4.50 \pm 0.1^{\mathrm{a}}$ & $1.20 \pm 0.1^{\mathrm{b}}$ \\
5 & $3.20 \pm 0.1^{\mathrm{a}}$ & $4.00 \pm 0.1^{\mathrm{b}}$ & $4.80 \pm 0.0^{\mathrm{a}}$ \\
6 & $3.50 \pm 0.1^{\mathrm{a}}$ & $----^{\mathrm{a}}$ & $3.50 \pm 0.0^{\mathrm{a}}$ \\
Total & $\mathbf{2 0 . 3 0} \pm \mathbf{0 . 6}$ & $\mathbf{2 2 . 2 0} \pm \mathbf{0 . 6}$ & $\mathbf{1 . 9 0} \pm \mathbf{0 . 0}$ \\
Mean $(\mathbf{X})$ & $\mathbf{3 . 3 8} \pm \mathbf{0 . 6}$ & $\mathbf{4 . 4 4} \pm \mathbf{0 . 1 2}$ & $\mathbf{1 . 0 5} \pm \mathbf{0 . 5}$ \\
$\mathbf{\%}$ Change & & $\mathbf{5 8 . 3 7 \%}$ & \\
\hline a,b,c: Values carrying the same letter in the same column are not significantly different at $5 \%$ level of significance.
\end{tabular}


Table 5: Blood glucose levels before and after administration of plant extract.

\begin{tabular}{|c|c|c|c|c|}
\hline \multirow[t]{2}{*}{ Group } & \multirow{2}{*}{$\begin{array}{l}\text { Concentration before } \\
\text { administration of the } \\
\text { extract }(\mathrm{mmol} / \mathrm{L})\end{array}$} & \multicolumn{3}{|c|}{$\begin{array}{l}\text { Concentration after administration of extract } \\
\qquad(\mathrm{mmol} / \mathrm{L})\end{array}$} \\
\hline & & 5 Days & 10 Days & 15 Days \\
\hline 1 & $4.90 \pm 0.1^{\mathrm{a}}$ & $3.00 \pm 0.2^{\mathrm{a}}$ & $2.70 \pm 0.3^{\mathrm{a}}$ & $2.00 \pm 0.3^{\mathrm{a}}$ \\
\hline 2 & $4.70 \pm 0.1^{\mathrm{a}}$ & $2.50 \pm 0.2^{\mathrm{b}}$ & $2.50 \pm 0.2^{\mathrm{a}}$ & $1.70 \pm 0.0^{\mathrm{a}}$ \\
\hline 3 & $4.10 \pm 0.2^{\mathrm{b}}$ & $3.00 \pm 0.3^{\mathrm{a}}$ & $2.55 \pm 0.3^{\mathrm{a}}$ & $1.90 \pm 0.2^{\mathrm{a}}$ \\
\hline 4 & $4.50 \pm 0.1^{\mathrm{a}}$ & $3.00 \pm 0.1^{\mathrm{a}}$ & $2.10 \pm 0.2^{\mathrm{b}}$ & $1.45 \pm 0.2^{\mathrm{a}}$ \\
\hline 5 & $4.00 \pm 0.1^{\mathrm{b}}$ & $3.20 \pm 0.1^{\mathrm{a}}$ & $2.00 \pm 0.3^{\mathrm{b}}$ & $1.75 \pm 0.1^{\mathrm{a}}$ \\
\hline 6 & $3.50 \pm 0.1^{\mathrm{c}}$ & $3.25 \pm 0.3^{\mathrm{a}}$ & $1.70 \pm 0.3^{\mathrm{c}}$ & $1.20 \pm 0.3^{b}$ \\
\hline Mean (X) & $4.20 \pm 0.9^{\mathrm{a}}$ & $2.90 \pm 0.2^{\mathrm{a}}$ & $2.29 \pm 0.0^{\mathrm{a}}$ & $1.66 \pm 0.8^{\mathrm{a}}$ \\
\hline \% Reduction & $3.38 \pm 0.6$ & 30.23 & 44.41 & 60.48 \\
\hline
\end{tabular}

a,b,c: Values carrying the same letter in the same column are not significantly different at 5\% level of significance.

\section{DISCUSSION}

Many plant remedies are known in folkloric medicine and are used in the management of several disorders including diabetes mellitus (Sofowara, 2006). Some of these herbal preparations have been validated by scientific studies and found to exert biological actions against diabetes mellitus and its complications (Ojiako and Nwanjo, 2006). The medicinal properties of some of these plants have been attributed to the biochemicals resident in the plant materials. In this study, some phytochemicals, vitamins and nutrients were identified quantitatively. This approach is deemed necessary to actually elucidate the mechanism of action of these anti-diabetic, hypoglycemic and antihyperglycemic components in the extracts of the vegetable extract. Although many workers have reported the role of phytochemicals and micronutrients in diabetes therapy (Nimenibo-Uadia,2003).The roles of micronutrients, anti-oxidants, vitamins and minerals in the management of diabetes mellitus have extensively been reviewed by Wilcox et al., 2004; Valko et al., 2007). Many antioxidant enzymes constitute one of the defense systems of the body especially in lipid metabolism that produces free radicals or reactive oxygen species (ROS).
Phytochemical constituents available in the plant extract were flavonoids, saponins, polyphenols and tannins. The flavonoids and polyphenol components of the extracts are well known antioxidants (Tiwari and Rao, 2002). For example Ginkgo biloba is reported to owe its antidiabetic effect to the presence of flavone glycosides present in the plant. Apart from these antioxidant properties, phenols are reported to inhibit alpha $(\alpha-)$ amylase, sucrase, as well as the action of sodium glucose transporter (S-GLUT-1) of the intestinal brush border cells, hence their antidiabetic action (Tiwari and Rao, 2002). It has also been reported that isoflavones, tannins, chlorgenic acids and crude saponins have been found by some workers to possess potent S-GLUT-1 mediated inhibition of glucose transport. Most of the vitamins identified in the extracts- Vit. $\mathrm{A}, \mathrm{C}$ and $\mathrm{E}$ are antioxidant vitamins and protect the cells or tissues of the diabetic against degenerative changes associated with the syndrome (Fasuyi et al., 2006; Padayatty et al., 2003; Gropper et al., 2009).

Bitter leaf $(V$. amygdalina $), \quad a$ traditional plant, is one of the herbs that has been studied a great deal. The results obtained from this recent study showed that administration of $2 \%, 4 \%, 6 \%, 8 \%$ and $10 \%$ of the extract respectively resulted in 
significant decrease in blood sugar level after periods of 5, 10 and 15 days. In Table 4, the highest hyperglycemic level of glucose was $4.90 \pm 0.1 \mathrm{mmol} / \mathrm{L}$, which was higher than the normal range of 2.9-3.50 $\mathrm{mmol} / \mathrm{L}$ (Aletor and Adeogu, 1995). The result in Table 5 showed that the leaf extract exhibited a profound reduction in blood glucose level of the diabetic and non-diabetic rats, with the highest reduction observed in group 4 rats $(8 \%$ extract) after 15 days. The lowest concentration of the extract (2\%) also exhibited the same reduction effect in groups 1 and 6 rats. The results are in agreement with those obtained by some workers who reported the hypoglycemic effect of $V$. amygdalina when administered to diabetic rats (Mazunder et al., 2003). Igile et al. (1995) reported that the leaves of bitter leaf (Vernonia amygdalina contain saponins, sesquiterpene lactones, sterols, glycosides, tannins and flavonoids. It has also been reported that the plant extract is generally non-toxic, but that excess consumption could be purgative. Many other workers have reported the non-toxic nature of the leaf extract either to the kidney or the liver (Atangwho et al., 2007b). It may also be possible that the leaf extract might possess the potency of inducing the synthesis of insulin or act as oral hypoglycemic drug by mediating some of the actions discussed above. In Table 5 , group 6 animals were equally given the plant extract despite the fact that diabetes mellitus was not induced in them. The extract equally reduced the glucose level, exhibiting hypoglycemic effect. Pharmacological treatment of diabetes mellitus in human subjects using Vernonia amygdalina leaf extracts may have future prospect as the identification and isolation of the active principles become very paramount. The presence of bioactive principles from vernonia amygdalina such as vernolide and vernodalol which are antibacterial can be very protective (Erasto et al., 2006). The inorganic constituents of the leaf such as potassium, zinc, calcium, manganese and chromium are believed to possess beneficial effect in the treatment of diabetes mellitus (Sofowara,
2006; Marles and Farnsworth, 1995; Aletor and Adlogun, 1995). The antidiabetic role of Vernonia amygdalina can be explained by the presence of several biochemicals resident in the plant and the level of chemical interactions (the synergistic interaction between vitamins $\mathrm{C}$ and E) both at the cellular and molecular levels. That the extract was able to reduce blood sugar levels of both the alloxan induced diabetic and normal rats is an indication of its hypoglycemic role and the potentiality for therapeutic trials.

\section{REFERENCES}

Akinpelu DA. 1999. Antimicrobial activity of Vernonia amygdalina leaves. Fitoterapea

- Journal for the Study of Medicinal Plants, 70(4): 432-34.

Akindahunsi AA, Salawu SO. 2005. Phytochemical screening and nutritentantinutrient composition of selected green leafy vegetables. African Journal of Biotechnology, 4(6): 497-501.

Aletor MU, Adeogun OA. 1995. Nutrient and Antinutrient components of some tropical leafy vegetables. Food Chemistry, 53: 375-380.

AOAC. 2000. Official methods of analysis. Association of official analytical chemists. Washington, DC.

Atangwho IJ, Ebong PO, Eyong MU, Eteng MU and Uboh PE 2007a Vernonia amygdalina Del: A potential prophylactic antidiabetic agent in lipids complication. Glob. J Pure Applied Sci., 3(1): 103-106.

Atangwho IJ, Ebong PE, Eyong EU, Eteng MU, Obi AU. 2007b. Effects of Vernonia amygdalina Del:leaf on kidney function of diabetic rats. Int. J. Pharm., 3(2): 143148.

Atangwho IJ, Ebong PE, Egbung GE, Eteng MU, Eyong MU. 2007c. Effects of Vernonia amygdalina Del:leaf on liver function in alloxan induced hyperglycemic rats. J. Pharm. Bioresource, 4(1): 1-7.

Amos AF, McCarty DJ. 1997. The rising global burden of Diabetic mellitus and its complication, estimates and projection 
for the year, 2010. Diabetic Medicare, 14: $57-59$.

Barneh AH. 1991. Diabetes mellitus in the tropics .Trans R. Society of Tropical Medicare, 85:324-38.

Bonsi MIK, Osuji PO, Tuah AK, Umunna NN. 1998a. Vernonia amygdalina as supplement to teff straw (Eragrostic leaf) fed to Ethiopian menz sheep. Agroforestry System, 31(3): 229-243.

Cheesbrough M. 1999. Measurement of blood or plasma glucose. In District Laboratory Practice in Tropical Countries (part 1, $1^{\text {st }}$ edn). Cambridge University Press: UK; 340-348.

Erasmus R, Blanco EB, Okesina AB. 1999. Assessment of glycemic control in stable type I Black South African Diabetics attending a pre-urban clinic. Postgraduate Med. J., 75: 603-06.

Erasto P, Grierson DS, Afolayan AJ. 2006. Bioactive sesquiterpene lactones in the leaves of Vernonia amygdalina. Journal of Ethnopharmacology, 106(1): 117-120.

Evans WA. 2005. Plants in African traditional medicines. An over view. In Trease and Evans Pharmacognosy $\left(15^{\text {th }}\right.$ edn). Saunders in Print Elsevier: India; 448-491.

Fasuyi AO. 2006. Nutritional potentials of some tropical vegetables leaf meal, chemical characterization and functional properties. African J. Biotechnology, 5(1): 49-53.

Gropper SS, Smith JL, Groff JJ. 2009. Riboflavins. In Advanced Nutrition and Human Metabolism $\quad\left(5^{\text {th }} \quad\right.$ edn $)$. Wadsworth; 329-333

Garrett RH, Grisham CM. 2005. Monosaccharides and sugar alcohols. In Biochemistry ( $3^{\text {rd }}$ edn). Publ. Tomson and Brookskole; 210-215.

Harbone JB. 1998. Methods of extraction and isolation. In Phytochemical Methods. Chapman and Hall: London; 60-66.

Igile GO, Oleszek W, Jurzyata M, Burd SJ. 1994. Flavonoids from Vernonia amygdalina and their anti-oxidant effects.
Agricultural and Food Chem., 42(11): 2445-2448.

Izevbigie EA, Bryant JL, Walker A. 2004. A novel natural inhibitor of extracellular signal regulated kinases and human breast cancer cell growth. Exptal. Bio. Med. (Maywood), 229(2): 163-169.

Kendall Powel. 2007. The two faces of fat. Nature, 447 (7144): 525-527.

Li Y, Schellhorn HE. 2007. New developments and novel therapeutic perspectives for vitamin C Critical Review. Journal of Nutrition, 137: 21712184.

Mazunder UK, Cropta M, Manikanda L, Haldar P. 2003. Evaluation of antiinflammatory activity of Vernonia spp. leaves extract in rats. Phytomedicines, 10:185-188.

Mbaya JC, Bornice F, Nagati K. 1996. Guidelines for the management of NIDDM in Africa. In a consensus Document, NOVO, HOR disk A/S Voluliagment, Greece, pp1-37.

Marles RJ, Farnsworth NR. 1995. Antidiabetic plants and their active content. Phytomedicines, 2(2): 137-189.

Nelson DL, Cox MM. 2005. Diabetes mellitus arises from defects in insulin production or action. In Principles of Biochemistry $\left(4^{\text {th }}\right.$ edn). Lehninger (ed). Freeman and Company: NewYork; 909-910.

Nimenibo-Uadia R. 2003. Effect of Vernonia amygdalina in alloxan induced diabetic albino rats. J. Med. Lab. Sci., 12(1): 2531.

Ohigeshi HM, Wiseka T. Takagak H. 1991. A bitter principle and a related glycoside of Vernonia amygdalina, a possible medical plant for wild champanzes. Agric Biological Chemistry, 55(4): 1201-1203.

Ojiako OA, Nwanjo HU. 2006. Is vernonia amygdalina hepatotoxic or hepatoprotective? Response from biochemical and toxicity studies on rats. African Journal of Biotechnology, 5(18): 1648-1651.

Padayatty S, Katz A, Wang Y, Eck P, Lee J, Chens CC, Dulta S, Leuine M. 2003. 
Vitamins as an antioxidant, evaluation of its role on disease prevention. J. Am. Coll. Nutrition, 22(1): 18-35.

Phyllistin AB, James FB. 2000. Tips for preventing food poisoning "Herbs" American No.1 Guide Natural health, $3^{\text {rd }}$ edn. Publ. Averge, No.9 pp. 383-386

Pinto JT, Rivlin RS. 1999. Garlic and other Allium vegetables in cancer prevention. In Nutritional Oncology, Haber D, Blackburn G, Go ULM (eds). Acad. Press: San Diego, C.A; 393-403.

Rivlin RS. 2001. Recent advances on the nutritional effects associated with the use of garlic as a supplement. Journal of American Society of Nutrition, 131: 95159545.

Sofowara NA. 2006. Medicinal Plants and Traditional Medicine in Africa. (Rep. edn). Spectrum Books Ltd: Ibadan; 150160.
Tiwari AK, Rao JM. 2002. Diabetes mellitus and multiple therapeutic approaches of phytochemicals. Present status and future prospects. Curri. Sci., 83(1): 30-37.

Vasudevan DM, Screekumari S. 2007. Diabetes mellitus. In Textbook of Biochemistry for Medical students $\left(5^{\text {th }}\right.$ edn). Publ. Jaypee Books: New Dehli; 143-146.

Valko M, Leibfritz D, Moncol J, Cronin M. 2007. Free radicals and antioxidants in normal physiological functions and human disease. Int. J. Biochem. Cell Biol., 39: 4484.

Wilcox JK, Ash SL, Catignani GL. 2004. Antioxidants and prevention of chronic diseases. Critical Reviews of Food Science and Nutrition, 44: 275-295. 